Flood Information for

Flood-Plain Planning

By Conrad D. Bue

GEOLOGICAL SURVEY CIRCULAR 539

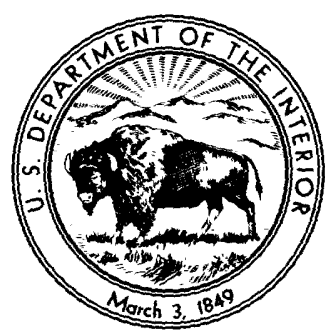




\section{United States Department of the Interior}

STEWART L. UDALL, Secretary

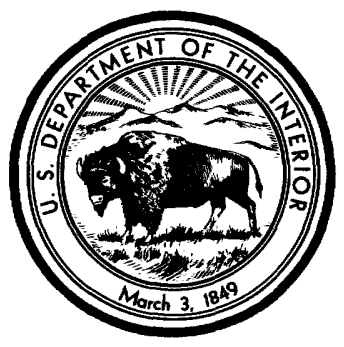

\section{Geological Survey}

William T. Pecora, Director

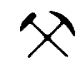

second printing 1967 


\section{CONTENTS}

Page Page

Abstract -

1 Basic data on floods.................. 6

Introduction -

The flood problem -

Flood-plain regulation--..-

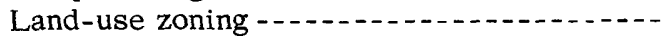

Flood proofing -....

Flood forecasting -.......................

Hydrologic investigations atlases -........-.

1 Other programs related to flood-plain

1 planning -

2 Corps of Engineers -

3 Tennessee Valley Authority -...........-. 8

4 Zoning by local governments, by John E.

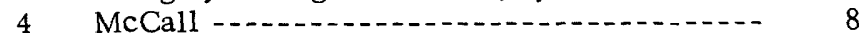

4 Selected references -..... 9

\section{ILLUSTRATIONS}

Figure 1. Photograph showing flood of March 12, 1963, on North Fork Kentucky River at

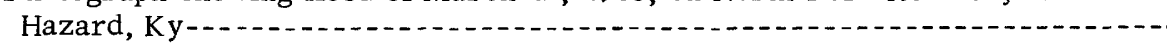

2. Part of a flood inundation map, showing how the flooded area is delineated -..................

3. Division of the 48 conterminous States into parts and subparts 


\section{.}




\title{
Flood Information for Flood-Plain Planning
}

\author{
By Conrad D. Bue
}

\begin{abstract}
Floods are natural and normal phenomena. They are catastrophic simply because man occupies the flood plain, the highwater channel of a river. Man occupies flood plains because it is convenient and profitable to do so, but he must purchase his occupancy at a price-either sustain flood damage, or provide floodcontrol facilities. Although large sums of money have been, and are being, spent for flood control, flood damage continues to mount. However, neither complete flood control nor abandonment of the flood plain is practicable. Flood plains are a valuable resource and will continue to be occupied, but the nature and degree of occupancy should be compatible with the risk involved and with the degree of protection that is practicable to provide. It is primarily to meet the needs for defining the risk that the floodinundation maps of the U.S. Geological Survey are prepared.
\end{abstract}

\section{INTRODUCTION}

Where flood damages have been relatively minor, they are usually permitted to continue. In someplaces this choice has been arrived at by a study which showed that the cost of flood protection was greater than the anticipated reduction in damage. Where flood damages become unbearably high, something is ultimately done to lessen them. Just what is done depends upon the nature of the developments on the flood plain and the physical and economic feasibility of providing protection.

By the Flood Control Act of 1936, the Federal Government first assumed responsibility for flood control on a national scale. At that time the Congress stipulated that the Federal Government would participate only in projects designed to protect cities and communities against catastrophic floods. But subsequent floodcontrol acts became progressively broader in scope, and now these acts, although still referred to as floodcontrol acts, constitute the main body of Federal law dealing with the development, utilization, and conservation of the Nation's water resources. "Floodcontrol law has become the legislative basis for the broadest and greatest programs of public works and resource development ever undertaken by the United States" (U.S. Senate, 1960).

In the last two or three decades much thought has been given to flood zoning as a means of abating flood losses and of reducing the mounting requirements for flood control. "Flood zoning" is the general term ap- plied to the various measures designed to control the use of the land within the flood plain. Flood zoning reduces damage by requiring that the floodplain be used for purposes not subject to flood damage, and by providing for an unobstructed floodway. The flood imundation maps of the U.S. Geological Survey are intended to aid those engaged in planning the best use of a river flood plain.

The purpose of this circular is to give the reader a broad view of the flood problem and to acquaint him with the nature and use of the flood-inundation maps of the U.S. Geological Survey.

\section{THE FLOOD PROBLEM}

Floods have always been recurrent events; they are natural and normal phenomena. Floods become a problem to man only when he competes with rivers for the use of the flood plains, the high-water channels of rivers (fig. 1). This competition between man and the rivers has been long and costly.

There is no complete record of flood damages that includes the effects of both the great and the ordinary floods. However, White (1958) gives an est i m a te of $\$ 329$ million as an average annual loss for the period 1936-55, based on figures from the U.S. Weather Bureau adjusted to the 1957 index. Loss of life as a consequence of floods has diminished during the past half century, owing to improved communication facilities, greater and more immediate availability of medical aid and rescue operations, the Weather Bureau's warning system, and perhaps a greater awareness of the flood hazard on the part of the public.

Property damage, on the other hand, is generally increasing, despite the expenditure of several billion dollars for flood control since the enactment of the Flood Control Act of 1936. Hoyt and Langbein (1955) found evidence of increased flooding during the past half century, but were mindful of the "long-term though irregular cycles in river behavior of which the past fifty years may represent a rising phase, which may again be reversed." Of the increase in reported flood damage, they ascribe about $\mathbf{4 5}$ percent to the increase in property values, 25 percent to an increase in flooding, and 30 percent to an increase in building and other uses on flood-hazard lands. 


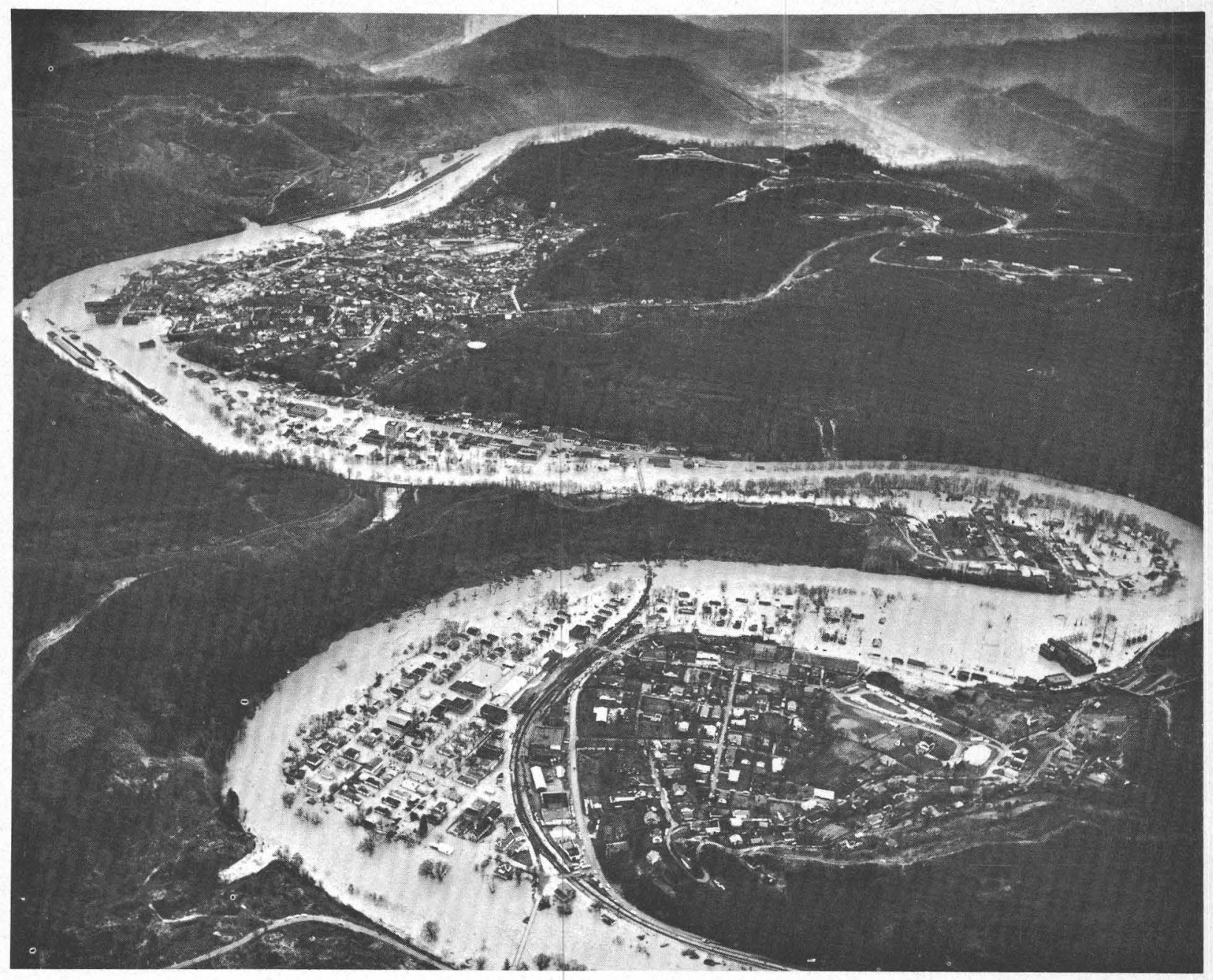

Figure 1.-Flood of March 12, 1963, on North Fork Kentucky River at Hazard, Ky. A graphic example of man and nature competing for a river flood plain. Photograph by "Courier-Journal and Louisville Times."

Flood problems, like our problems of water supply, are without any clear-cut solution. There are various approaches to the flood problem, all of which have been used and found effective to a degree. But no one measure is adequate in itself, except perhaps in minor floods, and if the flood is of rare magnitude all measures fail as a solution.

Solutions to flood problems fall into two broad categories-structural and nonstructural. Structural solutions include reservoirs, levees, floodways, and channel improvement; nonstructural consists mainly of flood plain regulation. This report is concerned with flood-plain regulation and with the use of Geological Survey maps and reports in defining flood risk.

\section{FLOOD-PLAIN REGULATION}

The purpose of flood-plain regulation is to obtain beneficial use of flood plains with a minimum of flood damage and a minimum of expense for flood protec- tion. In other words, the objective of flood-plain regulation is to promote uses of the flood plain so that the benefits derived from its use exceed the flooddamage plus the cost of providing a specified degree of protection. Indiscriminate use of floodplains invites great property damage and human suffering, including loss of life, whereas at the other extreme, complete abandonment of flood plains would be a sacrifice of a valuable national resource; the answer lies somewhere between those extremes, depending upon circumstances.

The techniques of flood-plain regulation include ( 1 ) land-use zoning, and (2) flood proofing. Application of these techniques depend on delineation of floodzones on a map. A subsequent section entitled "Hydrologic Investigations Atlases" describes how Geological Survey maps can aid in defining flood zones.

Nonstructural measures may be used effectively and profitably in conjunction with structural measures. 
For example, land-use zoning and flood proofing might be practiced in conjunction with a flood-control reservoir; a smaller reservoir might thus be required, or, a certain amount of potential reservoir storage might be released for other uses.

\section{LAND-USE ZONING}

Land-use zoning is the restriction of the use of flood-prone lands to minimize flood damage. "Zoning has been the most widely advocated of all the methods of regulating development in flood plains. This method has been proposed repeatedly for the past thirty years, but probably no more than eight communities had effective flood-plain zoning before $1955 .^{* * *}$ The reasons for non-use revolve mostly around (1) lack of basic data and (2) questionable legality" (Murphy, 1958). The lack of basic data is rapidly being corrected through the flood-information activities of the Geological Survey, the Corps of Engineers, and the Tennessee Valley Authority, and the question of legality has largely ceased to be a valid argument against zoning.

Flood protection can seldom be complete. There is always a probability that a greater flood will occur than has been experienced in recorded history. The provision of even a degree of flood prevention invites continued and increased use of the protected area; people tend to confuse a degree of protection with complete protection. Then when a flood occurs in excess of that for which protection has been provided, damage may be greater than if there had been no protection. Logically, then, some limitations should be placed on the type and degree of use of a protected area (Leopold and Maddock, 1954).

As discussed by Hoyt and Langbein (1955): "The primary goal of flood zoning [that is, land-use zoning] must be to prevent unwarranted constrictions that reduce the ability of the channel to carry water and thereby add to the height of floods. Thus there should be maintained a channel with capacity adequate to carry the discharge of a certain specified flood depending on local conditions. Where this is to be done "encroachment lines" beyond which no structure may extend, must be established after suitable field surveys. This is not to protect the structures, but so that the structures will not cause damage to other property. ${ }^{* * *}$ In general, therefore, the practice of setting encroachment limits is a balance between the principle of complete exclusion and no restrictions whatever. Coupled with regulations for flood-plain use outside the encroachment limits, it provides a fully economic arrangement."

Zoning, as described by Hoyt and Langbein, requires "*** consideration of flooding as a guide to the use of land. Most agriculture, grazing particularly, represents justifiable use of flood lands. So do parks and lakes built to replace channel storage lost when buildings and protective works were put up on the flood plain.*** Home building, on the other hand, is an ex- ample of the most unwise use of flood land. The use of flood land must be based, first, on what effects a particular use may have on flood heights, i.e., whether it aggravates the flood problem for users and others***."

The uses of the flood plain relate directly to the frequency of flooding, and regulations usually recognize certain "flood zones," defined as bands within which floods occur with comparable frequency. Permissible land uses within each flood zone wo"ld then correspond to the frequency of flooding in that zone. For example, a flood zone whose upper limit is the 1.5 -year flood would correspond to the channel itself, since the bankfull stage is reached with an average frequency of once in a 1.5-year period. In this flood zone, no obstructions would be permitted that would interfere with the free flow of water, and particularly bridges would be designed so as not to cause back water. A flood zone comprising the range from the 1.5to 10-year floods would also be kept free of f xed obstruction, and reserved for such uses as agriculture, parks, and roads. In a flood zone for the 10- to 100year interval, buildings might be permitted, either with first floor above the 100-year level or flood proofed. These possibilities are only examples of the application of flood maps to the delineation of flood zones, and of flood zones to flood-plain regulation.

According to Hogan (1963), "The constitutionality of zoning as a proper exercise of the police power t as been established for some time. ***While their [zoning ordinances] application to particular situations is sometimes held so arbitrary as to violate the due process clause, zoning ordinances have been held valid in virtually every case in which the zoning was reasonably related to the public health, safety, or general welfare."

In further discussing the legal aspects of floodplain zoning, Hogan states: "In the final analysis each ordinance setting up a land-use regulation must, in the words of the courts, "be reasonable and rot arbitrary." The principal criterion as to the reasonableness of flood-plain zoning ordinances involves a determination of the extent of the flood hazard. In other words, the regulations must bear a reasonable relation to the engineering data. In order to be reasorable the area, extent and elevation determinations of the land placed in the flood plain zone should be bas?d upon: historical evidence of flooding; a computed frequency of floods; an engineering study of flood potential; an analysis of the degree of flood protection affiorded by other methods of regulation; the degree of flood protection offered by engineering structures and whether or not development in the immediate future will increase or lessen the runoff. The uses to be permitted on the land subject to flooding should also take into consideration the anticipated growth of the area and the availability of non-flood land sufficient for the needs of the community. Once a legislative finding of fact as to flood hazard has been made, although not ccnclusive upon the courts, it will be accorded judicial considera- 
tion and deference. Therefore, there appears to be no legal reason why flood-plain zoning is any different from any other type of zoning except for the rather extensive amount of engineering research which must be conducted in order todetermine the area and elevation of the land to be included in any such district."

\section{FLOOD PROOFING}

Flood proofing is defined as adjustments to structures and contents to reduce flood damage. In some small flood-damage reduction programs, flood proofing alone may suffice; in most flood-damage reduction programs, flood proofing can be used effectively in conjunction with other measures.

Sheaffer (1960) gives three main classes of floodproofing measures: permanent, contingent, and emergency. Permanent measures provide permanent protection against the flood for which they were designed, such as permanently closing openings in outer walls with impervious material or installing automatic gatevalves on sewerlines in such a manner that when flood waters back up, the back pressure closes the valve. Contingent measures require action to make them operative, such as a sewer valve that must be closed manually, or a show window equipped with a remov able bulkhead that must be installed when a flood is imminent. Emergency measures are either improvised when needed or carried out according to prior emergency plans, such as temporary removal of merchandise from a threatened level, or rescheduling freight shipments to reduce the amount of damageable goods on hand.

\section{FLOOD FORECASTING}

Flood forecasting, although not a measure in itself, plays an important role in flood-damage reduction. It may save lives by enabling residents to evacuate the flood plain, and save property by enabling residents to put flood-proofing measures into effect.

Flood forecasting was started in the United States in 1871 by the Signal Service of the U.S. Army. In 1890 that activity was transferred to the then newly established U.S. Weather Bureau, and it is now performed at many River Forecast Centers of the Weather Bureau in the basins of large rivers. It is not possible to evaluate the dollar benefits of forecasting with any degree of accuracy, but Hoyt and Langbein (1955) estimated that the savings accredited to this service approximated 10 percent of the total annual flood loss. Undoubtedly many lives, too, have been saved through forecasting, although experience has shown that many people prefer to remain at home and face the flood rather than to move out.

Forecasts that are made public must be dependable; a poor or misleading forecast is worse that none. As pointed out by Hoyt and Langbein, a forecast that is too low catches many unprepared who might otherwise have been ready, and a forecast that is too high requires costly and unnecessary expenses and anxiety, and may result in the next forecast being greatly discounted. Decisions facing a forecaster may be exceedingly difficult to make. If, for example, as a flood is nearing its crest it threatens to overtop a levee or flood wall, a small difference in level may mean the difference between no flooding and disastrous flooding.

\section{HYDROLOGIC INVESTIGATIONS ATLASES}

The Geological Survey started its series of floodinformation atlases to provide information on flood hazards in easily read form. These atlases are published in the series entitled "Hydrologic Investigations Atlases." The flood-information atlases contain, briefly, a map showing the area inuntated by one or more known floods, graphs showing frequency of flood discharges and flood stages at a gagirg station in the area, a graph showing the height of annual floods above some specified elevation at a garing station for the period of record, and profiles of one or more known floods on one or more principal streams in the area. Some show cross-sections through the river channel and flood plains. The flood-frequency curves are generally for periods ranging from $25-50$ years. The text on the map explains how depth of flooding at points in the area can be estimated.

The primary purpose of the survey's flood-information atlas is to present historical dxcumentation of flooding by one or more floods that are known to have occurred. It must be emphasized, ho'vever, that the mere supplying of information as to where flood water has reached, and when, does not necessarily lead people to avoid flood danger. Building s are constructed in fair weather when no flood hazard is evident. In the absence of clear and present danger, the typical citizen may not be easily persuaded by a map to protect himself from a danger that seems remote. The information can, however, be transformed into action by land-use planning.

Flood damages begin with decisions to build on flood plains-often in disregard of the facts of flooding. Flood-damage abatement begins with definiton of the flood hazard, that is, presenting information on flooding of specific areas. Figure 2 is an example of how such information can be presented on a map.

Because the flood bound a ries shcwn on the floodinundation map are for a known flood the fact must be recognized that the flood might be exceeded at some time in the future. Sufficient data are shown to enable the user to determine, at a gaging station, the probable frequency of the flood that is mapped, unless the flood was of such magnitude that it is beyond the range through which frequency has been established by existing data. But the recurrence inter ${ }^{\circ}$ al determined at a gaging station does not necessar:ly apply to the 
flood level at all points on the map. For example, if the data indicated a 50-year recurrence interval at a gaging station on the main stream, that recurrence interval would not necessarily apply to the main stream above an upstream tributary or below a downstream tributary, or to the tributary itself. However, as the atlas presents a stage-frequency chart for the gaging station (or stations) and profiles for one or more floods, a profile of the desired frequency can be drawn parallel to the nearest profile with reasonably reliable results.

Flood-information atlases of the Geological Survey present hydrologic data concerning the extent, depth, and frequency of flooding that are essential for an appraisal of the hazards involved in occupancy and development of flood plains. They are intended to be a tool for individuals, governmental agencies, and others delegated with the responsibilities of solving existing flood problems and of formulating effective floodplain regulations that would minimize the creation of new flood probiems. The maps are useful for, but not limited to, preparing building and zoning regulations, locating waste disposal facilities, purchasing open space, developing recreational areas, and managing surface water in relation to the ground-water resources. Examples of the use of flood-hazard information are:

Flood-plain regulations: Establishment of reasonable controls over development of flood plains by local, regional, or State authorities requires information outlining the extent and degree of flood problems. Controls must be based on sound, impartial definition of the facts if they are to stand up in court as reasonable and fair.

Mortgage underwriting: Efforts by bankers or private lenders to consider flood hazard in writing mortgages usually falter because of the lack of proper information. The availability of loans usually controls construction.

Flood insurance: In order that premium rates may reflect the actual degree of risk, it is necessary to have accurate information concerning area, frequency, and depth of inundation.

Flood warning: Local authorities, civil defense workers, corporations, and individuals require precise advance information if they are to benefit from flood warnings. When, for example, there is a forecast that a flood will crest at 18 feet, it must be known precisely which homes, factories, and other structures may be affected.

Some examples of the uses of these flood atlases in northeastern Illinois, where 31 have already been completed, are: The communities of Highland Park, Wheeling, Harvey, Northfield, and Rolling Meadows have established zoning for residential buildings on basis of atlases. The Du Page County Forest Preserve, the Cook County Forest Preserve, and the Park Dis- trict of Highland Park have used the atlases in acquiring land subject to flooding in order to prevent encroachments on the flood plains that would result in property damages. Real estate appraisers for the Chicago office of the Veterans Administration have to refer to any available atlas to determine possible flood potential of property on which.VA loans have been applied for. After some recent flooding in south Cook County, the Northeastern Illinois Planning Commission was requested by the County Board president to prepare a flood-control plan for an area in the Harvey quadrangle; the hydrologic atlas for the Harvey quadrangle which had previously been prepared (Allen and May, 1964) was used as a basis for the commission's plan. Scheaffer (1964) estimated that the flood mapping in northeastern Illinois had a benefit-cost ratio of $40: 1$.

Twelve atlases have been completed to date (August 1966) for communities in Ohio. These atlases have been used for such purposes as highway design, floodinsurance studies, and approval by FHA of proposed housing developments.

\section{BASIC DATA ON FLOODS}

The Geological Survey began to compile streamflow records from a few gaging stations before 1890 . The number of gaging stations increased steadily, and now more than 8,000 gaging stations are operated continuously in the conterminous United States and 225 in Alaska and Hawaii. Flood information is also available at an additional 7,000 stations or more that have been operated for periods of various lengths.

The earliest published records consisted mainly of monthly discharges, daily gage heights, and rating tables whereby the user of the records could compute daily discharge if he wished to. After a few years the publication of daily discharge was started, and beginning with the 1914 streamflow reports annual extremes of discharge were added. Figure 3 is a map of the 48 conterminous States showing areas covered by the parts of the yearly reports on surface water supply of the United States. Since 1951, Parts 1, 2, 3, and 6 have been divided into subparts A and B. Part numbers have not been assigned to Alaska and Hawaii, for which similar reports also are published.

As a supplement to the annual streamflow reports, descriptions of major floods have been reported in nearly 100 water-supply papers. Flood reports contain detailed information on stages and discharges not presented in the annual streamflow reports, in addition to descriptive material and other pertinent data.

Regional flood-frequency reports are being prepared in a series of 19 water-supply papers, 1671-1689 inclusive, that will cover the conterminous United States. Each volume will be for a part, or subpart, as now used for publishing streamflow records. As of August 1966, 12 have been published-Parts 1-A,2-A, 


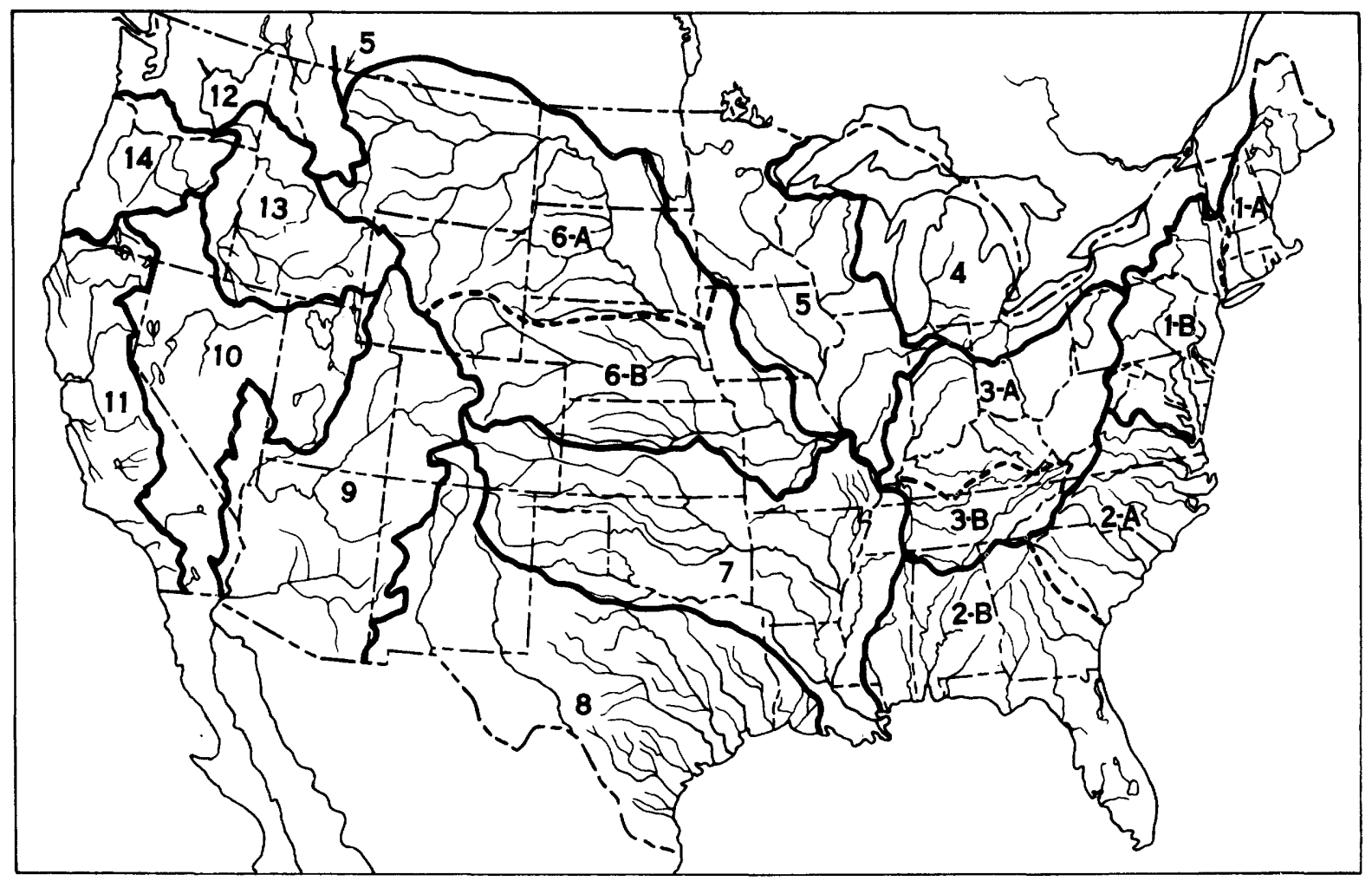

Figure 3.-Division of the 48 conterminous States into parts and subparts.

$3-\mathrm{A}, 3-\mathrm{B}, 4,7,8,9,10,12,13$, and 14-and those for Parts $2-\mathrm{B}, 6-\mathrm{A}$, and 11 are in process of publication. These reports are titled "Magnitude and frequency of floods in the United States," with an areal designation, for example, "Part 7, Lower Mississippi River basin."

The public is, however, usually more interested in extent, depth, and probable frequency of flooding than in discharge rates. Hence, flood-inundation maps are one of the most satisfactory and useful ways of presenting flood information for urban areas to the public.

The earliest flood-inundation maps were those that appeared in flood reports. The first Geological Survey flood report was Water-Supply Paper 88 by G. B. Hollister and M. O. Leighton (1903) describing the flood of 1902 on the Passaic River in New Jersey; this paper contained such a map. Many subsequent flood reports have contained maps showing areas inundated by the subject flood.

In 1959 the Geological Survey started a new series of flood-inundation maps published as hydrologic atlases, the first of which was Hydrologic Investigations Atlas HA-14, "Floods at Topeka, Kansas." The tempo of this program is accelerating in response to wide demand. As of November 1966, 63 atlases in 13 States and
Puerto Rico have been published and others are in preparation. The greatest concentration of atlases is in the environs of Chicago, where the Geological Survey is preparing a series of atlases in cooperation with the Northeastern Illinois Metropolitan Area Planning Commission. Twelve atlases have been prepared for communities in Ohio.

A manual for the guidance of those engaged in floodplain planning, titled "Hydraulic and Hydrologic Aspects of Flood-Plain Planning," by Sulo W. Wiitala, Karl R. Jetter, and Alan J. Sommerville, was prepared by the Geological Survey in cooperation with the Commonwealth of Pennsylvania and published in 1961 as Water-Supply Paper 1526. It is a study of Chartiers Creek at Carnegie, $\mathrm{Pa}$. The manual gives much the same type of information as the flood-inundation maps, but is much more comprehensive and describes the techniques used in considerable detail.

\section{OTHER PROGRAMS RELATED TO FLOOD-PLAIN PLANNING}

The Corps of Engineers and the Tennessee Valley Authority also collect and disseminate data of immediate application to flood-plain plannin-. Their programs are described briefly on the next fage. 


\section{CORPS OF ENGINEERS}

Section 206, Public Law 86-645 (Flood Control Act of 1960) provides in part "That, in recognition of the increasing use and development of the flood plains of the rivers of the United States and of the need for information on flood hazards to serve as a guide to such development, and as a basis for avoiding future flood hazards by regulation of use by States and municipalities, the Secretary of the Army, through the Chief of Engineers, Department of the Army, is hereby authorized to compile and disseminate information on floods and flood damages, including identification of areas subject to inundation by floods of various magnitudes and frequencies, and general criteria for guidance in the use of flood plain areas; and to provide engineering advice to local interests for their use in planning to ameliorate the flood hazard."

The major objectives under section 206 are:

A. To compile in a useful form and disseminate to State and local governmental agencies, information on floods and potential flood hazards, including identification of areas subject to inundation by floods of various magnitudes and frequencies.

B. To encourage optimum use of the Nation's river valleys by providing to State and local governmental agencies a factual basis for (1) reducing future flood damages and hazards through carefully considered and well-planned local regulation and use of the flood plains, (2) planning such advance protection as may be economically justified for prospective land uses that could not be undertaken without protection, and (3) preserving adequate floodway and channel rights-of-way and channel clearances.

C. To provide publicly available information for the guidance of private citizens and interests on use of the flood plains.

D. To reduce future expenditures for Federal projects to protect developments which, in the absence of the program, would have taken place, or for alleviation of flood problems arising from improper flood-plain development.

\section{TENNESSEE VALLEY AUTHORITY}

When the Tennessee Valley Authority was created by the Congress in 1933, it was assigned the control of floods in the Tennessee River basin as one of its primary objectives. Under this act TVA has built a system of multipurpose reservoirs, about one-fourth the cost of which has been allocated to flood control. Since the early 1950's TVA has been cooperating with the State of Tennessee and the other six Tennessee Valley
States and many local communities in a flood-damage prevention program. As the major part of its contribution to this program, TVA has prepared reports outlining the basic flood problems of local communities. Additional technical assistance and guidance is also available to the States and communities. The TVA reports do not, however, suggest solutions; solutions to the flood problems are left to the communities.

By letter dated March 9, 1959, the Board of Directors of the Tennessee Valley Authority submitted to the Congress a report entitled "A Program for Reducing the National Flood Damage Potential." The proposed program contains three major points:

A. An expanded program for collection, analysis, and wider use of flood data.

B. A broad approach to flood darrage abatement which includes preventive as well as corrective measures.

C. More active participation by State and local governments in solving flood problems.

\section{ZONING BY LOCAL GOVERN'MENTS}

$$
\text { By John E. McCall }
$$

Flood-plain studies are made to assist local communities in delineating or recommerding zones to which specific regulations should be applied.

Difficult problems and a series of technical decisions are thus left to the State and local official. Frequently these officials and their staffs have nc closely comparable experience to guide them in the hydrologic engineering and legal phases of flood zoning. Nevertheless, positive actions must be taken by the local officials if the potential benefits of flood-plain studies are to be fully realized. Fortunately, steadily growing numbers of engineers, lawyers, planners, and economists are becoming qualified to advise local government officials on the specific steps needed to institute flood-plain. zoning. Likewise, a considerable body of precedents is slowly building up in many States that furnish a model for others to follow.

It is not possible or practical to outline herein a specific course of action by local officials because State laws on property rights and "police powers" for zoning are quite variable and local or dinances even more so. Likewise, some but not all States have encroachment statutes that regulate building in the river channel or floodway, the provisions of which are far from uniform across the country. Perhaps even more importantly, differing local conditions of flooding, relative values of flood-plain lands, and attitudes of the citizens of the community prohibit any standard solution. However, one or more of the following suggestions may prove helpful in putting into use the results of a flood-plain study. 
1. Request the engineer or planning director of the municipality to contact officials of the State agency concerned with flood control and stream-channel encroachments. Usually this agency will also be coordinating the floodplain studies by the several Federal agencies to arrange priorities and to prevent duplication of effort. This State agency will likely be the best source of guidance on encroachment statutes, as well as specific State laws relating to flood zoning, and may be able to outline the steps to be taken and to furnish other staff assistance. Hopefully this agency can name other municipalities within the State which have already adopted flood-zoning codes or ordinances and may be able to suggest desirable modifications or alternatives based upon experience.

2. Consider retaining a firm of engineering or planning consultants with experience in the field of flood zoning. Such firms can develop the details quickly and for mula te a recommended ordinance, making full use of the information contained in the completed floodplain study. A consulting firm will be especially useful if the municipality has only a small technical staff or if that regular staff is fully committed on other work.

3. Request the cooperation and assistance of a river-basin planning commission, a watershed association, or a regional-planning group, if any exist within the area. Frequently such organizations can furnish staff assistance and advice and may be especially helpful in sponsoring public meetings to gain public understanding and endorsement of flood zoning.

4. Contact officials of State and Federal agencies concerned with urban redevelopment and acquisition of land for parks, recreation, and other open-space uses. Federal and State funds may be available to assist the municipality in obtaining development rights, easements, or fee title to flood-prone areas or long-range planning for conversion of land use on the flood plain.

5. Refer to published reports listed in the references contained herein. A section on "Implementation of Flood-Plain Regulation s" is given, for example, on pages 98-106 of the American Society of Civil Engineers Task Force report cited in the references.

6. Invite representatives of the Federal agency that has prepared the flood-plain study and representatives of appropriate State, regional, or other Federal agencies to appear before the municipal officials, including the planning and zoning boards, to present a brief summary of the work accomplished and to discuss its further implement a tion. These representatives may also be helpful in presenting background information at public meetirgs, provided that their testimony be restricted to their sphere of knowledge and assigned agency functions.

7. Recent development pertaining specifically to flood-plain management are Executive Order 11296, signed by the President on August 10, 1966, and House Document 465, 89th Congress, $2 \mathrm{~d}$ session, transmitted by the President to the Speaker of the House of Representatives by letter dated August 10, 1966. The Executive Order directs Federal agencies to evaluate flood hazard in locating federally owned or financed buildings, roads, and other facilities, and in disposing of Federal lands and properties. The House Document is a refort by a Task Force on Federal Flood Control Policy; it recommends specific action (1) to improve basic knowledge about flood hazard, (2) to coordinate and plan new developmerts on the flood plain, (3) to provide technical services to managers of flood-plain property, (4) to move toward a practical national prorram for flood insurance, and (5) to adjust Federal flood-control policy to sound criteria and changing needs.

\section{SELECTED REFERENCES}

Allen, Howard E., and May, V. Jeff, 1964, Floods in Harvey quadrangle, Illinois: U.S. Geol. Survey Hyd. Inv. Atlas HA-90.

American Society of Civil Engineers, Task Force on Flood Plain Regulations, Flood Control Committee of the Hydraulics Division, 1962, Guide for the development of flood plain regulations, progress report: Jour. of the Hydraulics Div., Am. Soc. Civil Engineers, v. 88, no. HY5, Proc. Paper 3264, p. 73119.

Burton, Ian, 1961, Education in the human us $:$ of flood plains: v. 60 , no. 8, p. 362-371.

Dalrymple, Tate, 1960, Flood-frequency analyses: U.S. Geol. Survey Water-Supply Paper 1543-A, 80 p.

Goddard, James E., 1963, Flood plain management improves Man's environment: Jour. Waterways and Harbors Div., Am. Soc. Civil Engineers, v. 89, no. WW4, Proc. Paper 3702, Nov. 1963, p. 67-84.

Hogan, Thomas M., 1963, State flood-plain zoning: Chicago, De Paul Law Rev., v. 12, no. 2, p. 246262.

Hoyt, William G., and Langbein, Walter B., 1955, Floods: Princeton, Princeton Univ. Press, 469 p. 
Kates, Robert W., 1962, Hazard and choice perception in flood plain management: Chicago, Chicago Univ. Dept. Geog. Research Paper 78, 157 p.

Leopold, Luna B., and Maddock, Thomas Jr., 1954, The flood control controversy: New York, The Ronald Press Co., 278 p.

Mitchell, W. D., 1954, Floods in Illinois, magnitude and frequency: Illinois Dept. Public Works and Bldgs., Div. Waterways, 386 p.

Murphy, Francis C., 1958, R egulat ing flood plain development: Chicago, Chicago Univ. Dept. Geog. Research Paper 56, 204 p.

Sheaffer, John R., 1960, Flood proofing: Chicago, Chicago Univ. Dept. Geog. Research P aper 65, $190 \mathrm{p}$.

1964, The use of flood maps in northeastern Illinois: Highway Research Board of the National Academy of Sciences, National Research Council, Highway Research Record no. 58, p. 44-46.

U.S. Congress, 1966, A unified National program for managing flood losses: House Doc. 465,89 th Cong., $2 \mathrm{~d}$ sess., $47 \mathrm{p}$.

U.S. Senate, Select Committee on Water Resources, 1960, Floods and flood control: Committee Print 15, 86th Cong., 2d sess., 77 p.
Weber, Eugene W., and Sutton, Walter G., 1965, Environmental effects of flood plain regulation: Jour. Hydraulics Div., V. 91, no. HY'4, Proc. Paper 4402 , p. 59-70.

White, Gilbert F., 1945, Human adjustment to floods: Chicago, Chicago Univ. Dept. Geog, 225 p.

ed., 1961, Papers on flood prob'ems: Chicago, Chicago Univ. Dept. Geog. Research Paper 70, $221 \mathrm{p}$.

1964 Choice of adjustment to floods: Chicago, Chicago Univ. Dept. Geog. Research Paper 93, $150 \mathrm{p}$.

White, Gilbert F., and others, 1958, Changes in urban occupance of flood plains in the United States: Chicago, Chicago Univ. Dept. Geog. P esearch Paper 57,235 p.

Wise, William S., 1957, Experiences in establishing stream channel encroachment limits in Connecticut: Northeastern States Conf. on Streamflow and Flood Control Proc, Princeton, N. J., 47 p.

Wood, Wilmer H., 1965, Federal flood hazard mapping in the United States: Chicago, Chicago Univ. Dept. Geog., Master's thesis, $34 \mathrm{p}$. 